\title{
JOURNAL.RU
}

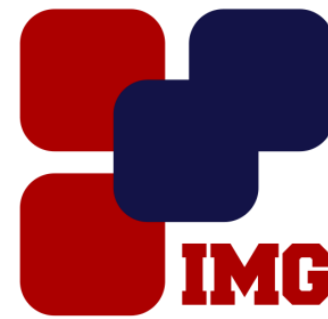

Iyanoy
Management
GRoup

Чиркова Н.В., Попова Т.А., Вечеркина Ж.В., Богатырева Ю.А., Плутахина А.А. Воронежский государственный медицинский университет имени Н. Н. Бурденко Воронеж, Россия

doi: 10.18411/lj-30-06-2017-09

idsp 000001:1j-30-06-2017-09

\section{Особенности профилактических мероприятий гиперестезии зубов препаратами «Флюрофилбесцветный»и «Сенсидент»}

Гиперестезия твердых тканей зубов среди некариозных поражений имеет высокую распространенность. В России, по последним исследованиям, у 40-70\% населения в возрасте 20-65 лет наблюдается гиперестезии зубов различной степени тяжести. Как правило, это пациенты в возрасте 21-58 лет, то есть молодые трудоспособные люди, что говорит не только о медицинской, но и социальной значимости этой проблемы. Причины, приводящие к развитию повышенной чувствительности, в основном связаны с возникновением дефектов твердых тканей зуба. Гиперестезия может проявляться как самостоятельный синдром, так и выделяться в качестве признака основного заболевания. Гиперчувствительность часто сопутствует некариозным поражениям: эрозиям, клиновидным дефектам, патологической стираемости, а также встречается при заболеваниях пародонта, которые сопровождаются рецессией десны и обнажением шеек зубов [3].Гиперестезия - это повышенная чувствительность тканей зуба к механическим, химическим и температурным раздражителям. В основе механизма возникновения гиперестезии лежит раздражение чувствительных отростков одонтобластов при истончении, увеличении пористости эмали, а также при обнажении дентина, что и приводит к возникновению болевых ощущений у пациентов [2].

Одним из современных направлений профилактики гиперестезии зубов является использование десенситайзеров дентина и реминерализирующих препаратов. Десенситайзеры дентинаспециально предназначенны для снижения и устранения гиперестезии твердых тканей зубов путем обтурации открытых 
дентинных канальцев и снижении возбудимости нервных окончаний. Задача реминерализующей терапии - восстановить физиологические условия для оптимизации, усиления процессов минерализации с целью возобновления физиологического преобладания процессов реминерализации над процессами деминерализации. В результате происходит восстановление поверхностного слоя поражённой эмали [1,5].

Фирмой «Целит» (Воронеж)предложено несколько препаратов для профилактики гиперестезии зубов.«Сенсидент»- десенситайзер в виде геля, в состав которого входят соли калия. Ионы калия, накапливаясь в дентинных канальцах, блокируют передачу нервных импульсов. Фторлак «Флюрофил бесцветный» представляет собой новый тройной акрилатный сополимер, содержащий в своем составе фторид натрия и фторид кальция в ионной форме. Малый размер частиц обеспечивает длительное и глубокое проникновение фтора и кальция в твердые ткани зуба, в частности, в дентинные канальцы. Образующаяся при нанесении данного фторлака на поверхности зуба пленка бесцветна, что имеет эстетическое значение для многих пациентов. Данные препараты обладает способностью не только уменьшать, но и снимать болевую чувствительность твердых тканей зубов [6]. Но в клинике ранее не проводилось изучения эффекта от комплексного применения представленных препаратов для профилактики гиперестезии зубов.

Материалом для исследования послужил контингент из 30 человек в возрасте 18-20 лет без выраженной сопутствующей патологии. Из них 10 (33 \%) мужчин и 20 (67 \%) женщин. Все пациенты были разделены на 3 группы по 10 человек в зависимости от $\mathrm{pH}$ ротовой жидкости:

1 группа - пациенты с нейтральной рН ротовой жидкости,

2 группа - со слабощелочной рН ротовой жидкости,

3 группа - со слабокислой рН ротовой жидкости.

В работе были использованы следующие методы исследования:визуально - инструментальный осмотр; индекс OHI-S (индекс гигиены полости рта); КОСРЭ-тест; определение рН ротовой жидкости (экспресс-метод).

Выбор данного комплекса методик был обусловлен возможностью широкого их использования на клиническом приеме. Методы просты в исполнении и дают возможность объективно оценить стоматологический статус пациента [4].

Измерение водородного показателя ротовой жидкостипроводили с помощью бумажных экспресс-полосок. Индикаторную полоску обследуемые 
держали в полости рта 2-3 секунды, а через 20-30 секунд результат сравнивали с контрольной цветовой шкалой.

Всем отобранным для научного исследования пациентам был определен уровень гигиены полости рта с помощью индекса OHI-S. Индекс OHI-S показал в $75 \%$ случаев удовлетворительный уровень гигиены полости рта у пациентов и в 25\% случаев - неудовлетворительный.

Затем всем пациентам был проведена профессиональная гигиена полости рта с целью получения в дальнейшем достоверных результатов исследования.

Профилактические мероприятия при гиперестезии зубов пациентам всех трех опытных групп проводились ежедневно. В начале после предварительного просушивания с помощью аппликатора наносили на чувствительные зоны зубов «Сенсидент» на 30-40 секунд, затем гель удаляли и покрывали зубы фторлаком «Флюрофил бесцветный». Полученная пленка сохранялась на эмали зубов до 24 часов.

Снижение болевой чувствительности отмечалось у всех пациентов уже после 1-ой процедуры. Полное исчезновение симптомов гиперестезии зубов наблюдалось после 2-3 сеансов у пациентов со слабощелочной и нейтральной pH ротовой жидкости, и после 3-4 процедур у пациентов со слабокислой $\mathrm{pH}$ ротовой жидкости.В процессе терапии гиперестезии зубов клиническая динамика отслеживалась не только визуально-инструментально, но и с помощью КОСРЭ-теста. Перед началом профилактических процедур пациентам на зуб шприцом наносили каплю солянокислого буферного раствора на 60 секунд, а затемпротравленный участок эмали в течение 1 минуты окрашивали $1 \%$ водным раствором метиленового синего. В последующие посещения проводилось повторное окрашивание зуба. Утрата протравленным участком свойства прокрашиваться расценивалось как полное его восстановление. Полное восстановление эмали наблюдалось на 2-3 день терапии у пациентов со слабощелочной и нейтральной $\mathrm{pH}$ ротовой жидкости, и на 3-4 день у пациентов со слабокислой $\mathrm{pH}$ ротовой жидкости.

Полученные показатели говорят о клинической эффективности профилактики гиперестезии зубов и повышении резистентности эмали зубов при комплексном применении препаратов «Флюрофилбесцветный» и «Сенсидент». 


\section{Литература}

1. Анализ профилактических мероприятий стоматологических заболеваний у детей / А.А. Смолина, В.А. Кунин, Ж.В. Вечеркина, Н. В. Чиркова / Системный анализ и управление в биомедицинских системах.- 2016.- Т.15, № 2.-С.338-341.

2. Коммунальная стоматология: учебно-методическое пособие / А.Н. Морозов [и др.].- Воронеж, 2016.-125 c.

3. Профилактическая стоматология: Учебник / Э. М. Кузьмина, О.О. Янушевич.- М.: Практическая медицина, 2016.- 544 с.

4. Симуляционное обучение в системе подготовки врача-стоматолога для улучшения качества стоматологической помощи / Есауленко И.Э.,Чиркова Н.В., Морозов А.Н., Вечеркина Ж.В. // Системный анализ и управление в биомедицинских системах. 2015. - Т.14, №2. - С.334-337.

5. Современный подход к проблеме качественного пломбирования зубов при лечении кариеса / Т.А. Попова [и др.] // Здоровье семьи-21 век, 2015.- Т. 1.- С. 301-304.

6. Эффективность применения фторлака фирмы «Целит» для лечения гиперестезии эмали при различной $\mathrm{pH}$ ротовой жидкости / Т.А. Попова [и др.] // Тенденции науки и образования в современном мире, 2016.- № 19-2.- С. 35-37. 